\title{
Review \\ The Belmont Valley integrated algae pond system in retrospect
}

\author{
Prudence M Mambo', Dirk K Westensee ${ }^{1}$, Bongumusa M Zuma and A Keith Cowan ${ }^{1 *}$ \\ 'Institute for Environmental Biotechnology, Rhodes University (EBRU), Grahamstown, 6140, South Africa
}

\begin{abstract}
Integrated Algae Pond Systems (IAPS) are a derivation of the Oswald-designed Algal Integrated Wastewater Pond Systems $\left(\right.$ AIWPS $^{\circ}$ ) and combine the use of anaerobic and aerobic bioprocesses to effect sewage treatment. IAPS technology was introduced to South Africa in 1996 and a pilot plant designed and commissioned at the Belmont Valley WWTW in Grahamstown. The system has been in continual use since implementation, and affords secondarily treated water for reclamation according to its design specifications, which most closely resemble those of the AIWPS Advanced Secondary Process. In this paper IAPS as a municipal sewage treatment technology is re-examined in relation to design and operation, the underpinning biochemistry of nutrient removal by algae is described, and a retrospective is provided on the demonstration system at the Belmont Valley WWTW. In addition to presenting details of the process flow, several shortcomings and/or oversights are highlighted and, in particular, the need for an appropriate tertiary treatment component. However, despite the use of IAPS for sewage treatment in many countries, this technology is still viewed with some scepticism. Thus, a major purpose of this overview is to provide a synthesis of available information on IAPS and an appraisal of its use for municipal sewage treatment.
\end{abstract}

Keywords: advanced integrated wastewater pond system, integrated algae pond systems, wastewater, algae, nutrient removal, sewage

\section{INTRODUCTION}

Municipal sewage is an anthropogenically contaminated water body or stream which varies significantly depending on its origin and reaction to environmental influences, chiefly rainfall and evaporation (Adewumi et al., 2010). Rainfall dilutes the effluent and evaporation has a concentrating effect (Adewumi et al., 2010; Ahmad et al., 2011). Origins of municipal wastewater may be inclusive of, but not limited to, households, industry and agriculture (Bdour et al., 2009) and its source directly impacts its composition. However, factors such as social behaviour, economics, type and number of industries, area, climate, water consumption and the type and condition of the sewer system all contribute significantly to sewage composition (Sonune and Ghate, 2004; Su et al., 2012; Travis et al., 2012). Municipal sewage may contain contaminants such as plastics, rags, plant debris, pathogenic bacteria, fats, greases, nitrates, phosphates, heavy metals, and other potentially hazardous compounds (Sonune and Ghate, 2004; Ansa et al., 2012). Unless removed or rendered harmless in the WWT process these can adversely affect the environment. Thus, any remedial process must achieve an appropriate concentration of minerals and nutrients to avoid any acute or gradual influx into the environment of xenobiotics and toxic compounds (Lettinga, 1996; Debelius et al., 2009; Sekomo et al., 2012). The South African Government, through the Department of Water Affairs (DWA) has therefore mandated the remediation of all effluent prior to discharge to the environment to ensure that effluent streams released by municipalities (and industries) comply and will not be detrimental and/or damaging to the environment.

\footnotetext{
To whom all correspondence should be addressed.

+27 (0)46 622-2656; e-mail: a.cowan@ru.ac.za

Received 26 March 2013; accepted in revised form 3 March 2014.
}

Innovation and advancement in the sector have proliferated wastewater treatment works (WWTW) and new process technologies are regularly made available as strategies to improve the management and remediation of wastewater (Bdour et al., 2009). Even so, management of WWT and control of final effluent quality/discharge is complex and some of the associated challenges include land, capacity, operations, maintenance and repair, technology developments, climate change, water course accessibility, and sustainability (Muga and Mihelcic, 2008; Gravelet-Blondin et al., 1997). These, coupled with available financial resources, directly impact wastewater infrastructure by influencing design, construction, operation, inspection, maintenance, and the overall efficiency of the WWTW (Korf et al., 1996). Since WWT is not a free-market enterprise in South Africa, acceptable process technologies are viewed by many as those that are either already optimised or can be immediately optimised, and without consideration of additional energy and monetary costs.

Wastewater treatment technologies currently deployed in South Africa for the treatment of municipal sewage include waste stabilisation ponds (WS) or oxidation ponds (OP), activated sludge plants (AS), bio-filtration (BF), biological nutrient removal (BNR), constructed wetlands (CW), and more (Adewumi et al., 2010; Oller et al., 2011; Tomar and Suthar, 2011). South Africa has approximately 970 municipal WWTWs which together treat an effluent stream of $7589000 \mathrm{k} \ell \cdot \mathrm{d}^{-1}$ at an operational cost in excess of ZAR3.5 billion per year. Regional distribution of these WWTW according to size shows differences between the nine provinces:

- Gauteng Province has a relatively high number of medium $\left(2-10 \mathrm{M} \ell \cdot \mathrm{d}^{-1}\right)$ and large $\left(10-25 \mathrm{M \ell} \cdot \mathrm{d}^{-1}\right) \mathrm{WWTWs}$, with fewer micro $\left(<0.5 \mathrm{M \ell} \cdot \mathrm{d}^{-1}\right)$ and small size $\left(0.5-2 \mathrm{M \ell} \cdot \mathrm{d}^{-1}\right)$ plants.

- Eastern Cape, Northern Cape, Mpumalanga and Limpopo provinces mainly have micro-size and small size plants.

- North West, KwaZulu-Natal and Free State have a wider 
spread of WWTWs across all the plant size categories.

- Western Cape has a spread of WWTW sizes similar to the national situation.

Thus more than $80 \%$ of municipal WWTWs in South Africa treat less than $10 \mathrm{M \ell} \cdot \mathrm{d}^{-1}$ and more than $50 \%$ of all WWTWs are micro-sized, while the preferred technologies are WS and AS at $41 \%$ and $35 \%$ respectively. Due to a paucity of information it is not possible to determine what proportion of the estimated total effluent stream (viz. $7589000 \mathrm{k} \ell \cdot \mathrm{d}^{-1}$ ) is treated by each technology. Suffice it to say, together with bio-filtration at $16 \%$, the range of WWT technologies commissioned by municipalities in South Africa is particularly narrow but distinctly biological.

Biological remediation of wastewater has for many years generally been favoured over conventional treatment techniques, even in light of the major limitation which is sensitivity to toxic components (Korf et al., 1996). Contemporary evaluation seems to share this opinion and is based largely on the costs involved in the construction and maintenance of biological treatment facilities (Cisneros et al., 2011). Toxicity, while a potential hazard to the microbial biocatalysts used in wastewater treatment, may be attributed to content and composition and factors such as shifts in $\mathrm{pH}$ and temperature (Muga and Mihelcic, 2008; Chan et al., 2009). Typically, it is maintenance of optimum activity of the biocatalysts that completely degrades organic pollutants (Gori et al., 2011; Mo and Zang, 2012; Daelman et al., 2012) and effects mineral and nutrient removal to yield a treated effluent that can be discharged regardless of shock loads (Gori et al., 2011; Rodriguez-Garcia et al., 2012).

The primary goal of the National Waste Management Strategy (NWMS) is the achievement of the objectives of the Waste Act (Act 59 of 2008) (Republic of South Africa, 2008), which are, in summary: (i) minimising pollution, environmental degradation and the consumption of natural resources, (ii) implementing the waste hierarchy, (iii) balancing the need for ecologically sustainable development with economic and social development, and (iv) promoting universal and affordable waste services (NWMS). Framed within the context of the overall goals, approach and regulatory model of the NWMS, the introduction of a new WWT technology requires demonstration of proficiency, education, and increased awareness amongst all stakeholders including the public at large, the three spheres of government, and the private sector. The South African Government, parastatal and non-governmental organisations and citizens share a common concern regarding the national crisis relating to small and medium municipal WWTW, many of which are currently in a state of disrepair and are blamed for disease outbreak and infant mortality. A skills shortage, apparent lack of will to address these issues due mainly to the high costs of infrastructure repair and upgrade, and poor technology choices have not helped the situation. While any and all exposure and attention to this problem is real, there is the risk that efforts to mitigate the crisis will sow seeds for a new one through inappropriate or unsustainable technology choices. Population growth and migration patterns, financial constraints at local government level, water shortages in many areas, the shortage and cost of skilled personnel and the cost of electricity, among others, all challenge this choice. There are alternative technologies including algal ponding systems (Horjus et al., 2010). But are these being adapted for adoption in a changing South African scenario? (Laxton, 2010).

This paper presents an overview of Algal Integrated Wastewater Pond Systems (AIWPS)/Integrated Algae Pond
Systems (IAPS) as a municipal sewage treatment technology, a retrospective on its introduction into the South African water sector, and a summary of current knowledge about this bioprocess technology.

\section{IAPS as a bioprocess technology for wastewater treatment}

Sewage treatment typically comprises 5 distinct phases. Primary treatment involves removal of suspended solids. Removal of dissolved biodegradable organic matter is a secondary treatment that reduces BOD to a level sufficient to prevent oxygen depletion of the water body into which the effluent flows. Nitrogen and phosphorus are removed by tertiary treatment to minimise growth of algae and other aquatic plants. Removal of refractory organic compounds is achieved by quaternary treatment while quinary treatment removes dissolved organics and salts including heavy metals. Successful waste treatment technologies should be sustainable, support periurban primary industry such as agriculture, prevent exploitation of water reserves and other resources, and enhance the quality of life of the community (Wang et al., 2012). Wastewater treatment must be biologically/mechanically rigorous, ecologically sound and environmentally friendly (Golueke and Oswald, 1963; Oswald, 1991, 1995) and the WWTW solid, able to withstand the elements and require minimal maintenance over an extended period of time (Wallis et al., 2008; González et al., 2012). Thus, for an implemented technology to be considered a sustainable process its use should, over the medium- to long-term, lower the overall cost without sacrificing reliability and efficiency (Katukiza et al., 2012).

Waste stabilisation (WS) ponds are a technology used prolifically by South African municipalities. As stated by Oswald (1995) 'The greatest advantages of ponds are their simplicity, economy, and reliability; their greatest drawbacks are their high land use, their potential for odour, and their tendency to eutrophy and fill in with sludge and to become less effective with age.' Research to maintain the advantages of WS ponds while mitigating the drawbacks resulted in the innovation known as the AIWPS (Oswald et al., 1957), which is still utilised globally for the remediation of domestic wastewater (Oswald, 1995; Green et al., 1995b; Craggs et al., 1996b; Craggs, 2005; Park et al., 2011a).

IAPS as a wastewater technology is a derivation of the AIWPS. Focus was initially on the symbiotic relationship between algae and bacteria in wastewater treatment (Oswald et al., 1955). Later, the term photosynthetic oxygenation was coined (Oswald et al., 1957) and used to describe the aeration effect caused by algal activity on treated wastewater (Ludwig et al., 1951, 1952; Oswald et al., 1953b, 1955). By 1957, Oswald had established the High Rate Algae Oxidation Pond (HRAOP). This algae-containing raceway amalgamated wastewater remediation via biological oxygenation and nutrient removal and led eventually to the fully developed bioprocess system (Oswald et al., 1957).

The system is designed to passively and biologically remediate domestic wastewater (Oswald, 1991). Based on studies at St Helena and Hollister in California, Oswald concluded that when properly designed systems were not only economical and effective but attractive and problem free. Moreover, AIWPS was deemed to provide for adequate, simple, and reliable wastewater treatment and afford communities opportunities for reclamation and environmental enhancement.

There are several versions of AIWPS and these have been 
categorised into first-, second- and third-generation processes depending on the quality of the final effluent required (Green, 1996). First=generation systems remediate domestic wastewater to a standard suitable for discharge to the environment whereas second- and third-generation AIWPS are self-sustaining and allow for the harvesting of methane, reclamation of water and in some cases harvesting of algae biomass (Green, 1996).

Like AIWPS, the IAPS relies on the combined activity of methane fermentation and photosynthetic oxygenation by algae coupled with biological oxidation in the high-rate ponds to remediate domestic wastewater. Furthermore, it uses gravity, solar energy and biological activity to treat wastewater (Downing et al., 2002) by processes that efficiently exploit the natural functionality of anaerobic, facultative and aerobic microorganisms within the system (Oswald, 1995; Craggs et al., 1996a), which comprises an in-pond digester (IPD), an advanced facultative pond (AFP), high-rate algae oxidation ponds (HRAOP), algae settling ponds (ASP) and maturation ponds (MP). A high-quality tertiary treated water can be reclaimed following filtration and UV sterilisation. As stated by Oswald (1990) 'when properly designed in appropriate locations, the systems virtually eliminate sludge disposal, minimise power use, require less land than conventional ponds, and are much more reliable and economical than mechanical systems of equal capacity'. Thus, IAPS is not just an adaptation of traditional pond systems but a design incorporating a series of low-cost reactors. No sludge management is required and the time in which sludge residues accumulate to require removal and disposal is of the order of decades. Carbon is transformed through two important mechanisms: methane fermentation and biological assimilation by microalgae. The conversion of waste organic solids to methane, nitrogen gas and carbon dioxide via methane fermentation and the assimilation of organic and inorganic carbon into algal biomass via photosynthesis provide the basis for primary, secondary, and tertiary treatment (Green et al., 1995a).

\section{IAPS design and operation}

Primary treatment takes place in an advanced facultative pond (AFP) which houses the in-pond anaerobic digester (IPD). The IPD is the point of entry of raw wastewater into the system and is responsible for the anaerobic decomposition of organic matter (Oswald, 1995). A coupled IPD/AFP promotes the deposition of organic material from suspension to facilitate decomposition at the base of the pond (Oswald, 1995). After 30 years of operation in the United States, sludge removal from the fermentation pits has yet to be conducted (Green et al., 1996; Daelman et al., 2012; Katukiza et al., 2012). The AFP is designed to reduce the $\mathrm{BOD}$ significantly and buffer the effluent prior to transfer to high-rate algae oxidation ponds (HRAOPs), while the aerobic surface layer of the pond neutralises odour-causing compounds, e.g., hydrogen sulphide (Lettinga, 1996; Oswald, 1995; Green et al., 1996; Muga and Mihelcic, 2008).

Secondary treatment is carried out in HRAOPs operated in series in which nutrients are extracted by a rapidly growing naturally occurring algae biomass. Algae photosynthesis directly supplies aerobic heterotrophic bacteria with oxygen, while the bacteria in turn oxidise recalcitrant material to increase the nutrient load in solution. It is the assimilation of waterborne nutrients such as nitrate, ammonium and phosphates, together with photosynthetic carbon reduction, that drives algae growth and development. Typically, HRAOPs are $0.1-0.5 \mathrm{~m}$ deep and the entire water column is oxygenated by both algae photosynthesis and paddlewheel mixing. The paddlewheel pumps water at a specific linear velocity and the action of the paddles on the water surface causes sufficient turbulence to allow for the introduction of oxygen, and $\mathrm{CO}_{2}$, from the outside air. Total oxygenation capacity of the pond and the installed power of the paddlewheel give an oxygenation efficiency of $15 \mathrm{kgO} \cdot \mathrm{kW} \cdot \mathrm{h}^{-1}$, which is a factor of 10 better than most mechanical aerators (Oswald, 1988; 1990). Thus, oxygenation capacity of HRAOPs can be contrasted with mechanical aerators which rarely transfer oxygen from air to water at more than $1 \mathrm{~kg} \cdot \mathrm{kW} \cdot \mathrm{h}^{-1}$, indicating that photosynthetic oxygenation is 10-100 times more efficient as all energy is solar derived.

Although $\mathrm{CO}_{2}$ availability within wastewater treatment HRAOPs depends primarily on the heterotrophic oxidation of organic compounds by bacteria (Weissman and Goebel, 1987; Oswald, 1988; Craggs, 2005), domestic sewage typically contains insufficient carbon to fully support optimal algal production (3-7 C:N ratio in sewage versus 6-15 C:N in algal biomass) (Benemann et al., 2003). Recently it was shown that addition of $\mathrm{CO}_{2}$ to wastewater HRAOPs enhanced algal productivity by at least 30\% (Park and Craggs, 2011b) and reduced nitrogen loss by ammonia volatilisation providing more nitrogen for recovery by assimilation into biomass (Park and Craggs, 2011). Even so, unicellular green algae and cyanobacteria cultivated in ambient air levels of $\mathrm{CO}_{2}$ develop a dissolved inorganic carbon (DIC) concentrating mechanism (also called a $\mathrm{CO}_{2}$ concentrating mechanism or CCM) which is suppressed when cultured at elevated $\mathrm{CO}_{2}$ and inhibited by $\mathrm{O}_{2}$ (Ghoshal and Goyal, 2001). Similarly, denitrification and dissimilation, which converts nitrate to nitrogen gas, only occur in the absence of oxygen (Mitchell, 1974). In short, oxygen decreases the denitrification rate even if denitrifiers possess aerobic denitrification ability (Patureau et al., 1996). It might therefore be expected that the very high oxygenation capacity of HRAOPs would limit both growth of algae and denitrification. Although higher dissolved oxygen does favour nitrification, denitrification (and nitrification) rates increase with increasing temperature and the diel (i.e. during the adjoining dark period) loss of nitrogen via denitrification for algae ponds appears to be $15-25 \%$ of total influent nitrogen (Zimmo et al., 2004).

For growth, the mechanism by which inorganic carbon species are taken up by algae involves the light-induced drawdown of inorganic carbon by photosynthetic carbon reduction which maintains a concentration gradient between the external medium and the active site of the primary photosynthetic enzyme, ribulose bisphosphate carboxylase oxygenase (Raven and Hurd, 2012). $\mathrm{CO}_{2}$ reacts in water and equilibrium is established between $\mathrm{CO}_{2}$ and carbonic acid $\left(\mathrm{H}_{2} \mathrm{CO}_{3}\right)$. The conversion of $\mathrm{CO}_{2}$ to $\mathrm{H}_{2} \mathrm{CO}_{3}$ is kinetically slow and at equilibrium only a fraction of $\mathrm{CO}_{2}$ exists as $\mathrm{H}_{2} \mathrm{CO}_{3}$ with most remaining as solvated molecular $\mathrm{CO}_{2}$. Carbonic acid dissociates in water in two steps to produce carbonate anions as follows:

$\mathrm{H}_{2} \mathrm{CO}_{3}+\mathrm{H}_{2} \mathrm{O} \leftrightarrow \mathrm{H}_{3} \mathrm{O}^{+}+\mathrm{HCO}_{3}^{-}\left(p K_{a 1}\right.$ at $\left.25^{\circ} \mathrm{C}=6.37\right)$ and;

$\mathrm{HCO}_{3}{ }^{-}+\mathrm{H}_{2} \mathrm{O} \leftrightarrow \mathrm{H}_{3} \mathrm{O}^{+}+\mathrm{CO}_{3}{ }^{2-}\left(p K_{a 2}\right.$ at $\left.25^{\circ} \mathrm{C}=10.25\right)$.

It is the formation of carbonate ions and their interaction with cations that leads to deposition of insoluble metal carbonates (e.g. $\mathrm{CaCO}_{3} ; \mathrm{MgCO}_{3}$ ) and which provides an additional driving force (Lide, 2006). Consequently, net photosynthetic rate of an algae pond at optimal depth $(0.3 \mathrm{~m})$ and under optimal light and temperature is almost always constant at approximately $10 \mathrm{t}(\mathrm{C}) \cdot \mathrm{ha}^{-1} \cdot \mathrm{y}^{-1}$ over the course of a day, because any increase in cell density, or decrease in photosynthetically active radiation, proportionately reduces the optimum pond depth and vice versa (Grobbelaar, 2007; Ritchie and Larkum, 2013). Even 
so, continual gravitation of effluent from the first HRAOP, via algae settling ponds (ASP), to the second HRAOP removes some of the accumulated algae biomass (and residual bacteria) to mitigate substantive changes in optimum pond depth thereby increasing nutrient abstraction efficiency (Oswald, 1995). In addition, sustained algae photosynthetic activity coupled with nitrification and nitrate consumption leads to an increase in medium $\mathrm{pH}$. Most of the energy for nitrate assimilation arises from photosynthesis, photosynthesis is also reported to be responsible for light regulation of nitrate reductase gene expression and activity (Lillo et al., 1996; Oswald et al., 2001), and linear electron flow and generation of reducing equivalents are promoted by photosystem 1 (PS l) light absorption which is believed to facilitate reduction of assimilated nitrate alongside $\mathrm{CO}_{2}$ (Sherameti et al., 2002). Thus, as long as nitrate is abstracted, reduced to ammonium and the ammonium assimilated into amino nitrogen, a 1:1 alkalinisation in relation to nitrate consumption is maintained (Ullrich and Novacky, 1990; Mistrik and Ullrich, 1996; Ullrich et al., 1998).

Alkalinisation in the HRAOPs has been suggested as a mechanism, separate from biological assimilation, to promote removal of phosphate in the form of an insoluble hydroxyapatite. Thus, elevated $\mathrm{pH}(>10)$ can stimulate not only ammonia-N removal from the HRAOP by ammonia volatilisation but phosphorus removal through phosphate precipitation with calcium, magnesium and non-chelated ferric iron (García et al., 2000; Craggs, 2005).

The above account on the biochemistry of nutrient abstraction and assimilation into biomass in HRAOPs has ignored, for the sake of brevity, some critical environmental (light and temperature), operational and other biological factors (zooplankton grazers and algal pathogens) that do impact wastewater treatment. However, this omission only serves to further strengthen the assertion by Oswald (1990) that correct design, locality and operation are paramount for successful implementation of this bioprocess technology. Secondary and tertiary treatment of wastewater can be fully accounted for by passage through a series of HRAOPs. Ideally suited to warm climates in which high BOD removal capacity is easily realised, these systems retain all of the advantages of WS ponds, and while land requirements are substantially more than needed for AS (not accounting for land used in sludge management), operational and capital costs have been estimated at half and one fifth, respectively, of those required for AS (Park et al., 2011b; Craggs et al., 2011).

The final reaction in the AIWPS/IAPS bioprocess is tertiary treatment, usually achieved in a series of maturation ponds (MP) or by filtration (e.g. slow sand filter). Maturation ponds hold secondary treated effluent and are typically positioned downstream from conventional treatment systems (Shillinglaw, 1977). The main function of maturation ponds is additional polishing of the water to clean and remove any residual pathogens carried forward from the secondary treatment process (Mara, 2005). Prevailing environmental conditions such as: high $\mathrm{pH}$, low temperature, high dissolved oxygen (DO) and ultraviolet radiation are exploited (Von Sperling and De Lemos Chernicharo, 2005) and usually 2 or 3 ponds are constructed in series to provide the retention time (12 days) needed for adequate pathogen removal. Maturation ponds provide little or no biological stratification, have high algae diversity which increases further across a pond series, and tend to be fully oxygenated throughout the day providing ideal conditions for faecal coliform/pathogen removal (Mara, 2005). A high $\mathrm{pH}$ is found in maturation ponds which impacts faecal bacteria mortality (Von Sperling, 2007) and enhances nitrogen removal both by assimilation into biomass and loss via volatilisation (Kayombo et al., 2005). In fact, ammonia removal in maturation ponds exceeds that of other tertiary treatment processes (e.g. constructed wetland), and in a comparative assessment was second only to aerated rock filtration (Johnson et al., 2007). Quaternary and/or quinary treatment are not typically components of AIWPS/IAPS wastewater treatment systems and will not be discussed here.

\section{IAPS as a global wastewater treatment technology}

During the past 6 decades IAPS have been successfully applied in America, Australia, Belgium, Brazil, Canada, China,

Egypt, Ethiopia, France, Germany, India, Ireland, Israel, Italy, Kuwait, Mexico, Morocco, New Zealand, The Netherlands, Philippines, Portugal, Scotland, Singapore, South Africa, Spain, Switzerland, Thailand, Vietnam and Zimbabwe (Oswald, 1995). More recent deployments of this bioprocess technology are presented in Table 1. As a green technology, algae systems address imperative issues such as global warming and climate change (Wallis et al., 2008). Algae biomass generated by the remediation of wastewater serves as a carbon sink, thereby mitigating the negative effects of $\mathrm{CO}_{2}$ as a greenhouse gas (Green et al., 1995a), which may be used to justify the use of algae ponds as a sustainable technology, economical and environmentally friendly, which alleviates pressure on environmental water reserves (Oswald, 1995). Furthermore, IAPS is a versatile and passive bioprocess that can be used to remediate, in addition to domestic sewage, brewery effluent, food processing waste, industrial effluent and abattoir waste (Rose et al., 1996; Boshoff et al., 2004; Van Hille et al., 1999).

Rhodes University commissioned and built an Oswalddesigned version of the AIWPS, the IAPS, specifically for South African conditions. This pilot-scale demonstration is located at the Belmont Valley WWTW where it receives and treats a constant supply of raw domestic sewage extracted from a splitter box immediately after the inlet works. A

\begin{tabular}{|l|l|l|l|l|l|l|}
\hline \multicolumn{7}{|c|}{ Examples of global deployment of IAPS since 2000 } \\
\hline Country & Climate & Treatment & Performance & Deployed & Reference \\
\hline China & Monsoon & HRAOP $(\times 2)$ & Not disclosed & 2002 & Chen et al., 2003 \\
\hline Morocco & Mediterranean & HRAOP $(\times 2)$ & Not disclosed & 2003 & El Hamouri et al., 2003 \\
\hline New Zealand & Temperate & HRAOP $(\times 2)$ & $100 \%$ faecal coliform disinfection & 2001 & Craggs et al., 2003 \\
\hline New Zealand & Temperate & HRAOP $(\times 4)$ & $\begin{array}{l}82-91 \% \text { BOD, 64-67\% NH4,14-24\% } \\
\text { P, }>99 \% \text { coliform removal, pH 9.3 }\end{array}$ & 2010 & Broekhuizen et al., 2012 \\
\hline Spain & Mediterranean & HRAOP $(\times 2)$ & Not disclosed & 2006 & Garcia et al., 2006 \\
\hline Sweden & Cold & HRAOP $(\times 2)$ & $97 \%$ BOD, 64\% P, 90\% N removal & 2003 & Gröndlund et al., 2004 \\
\hline
\end{tabular}




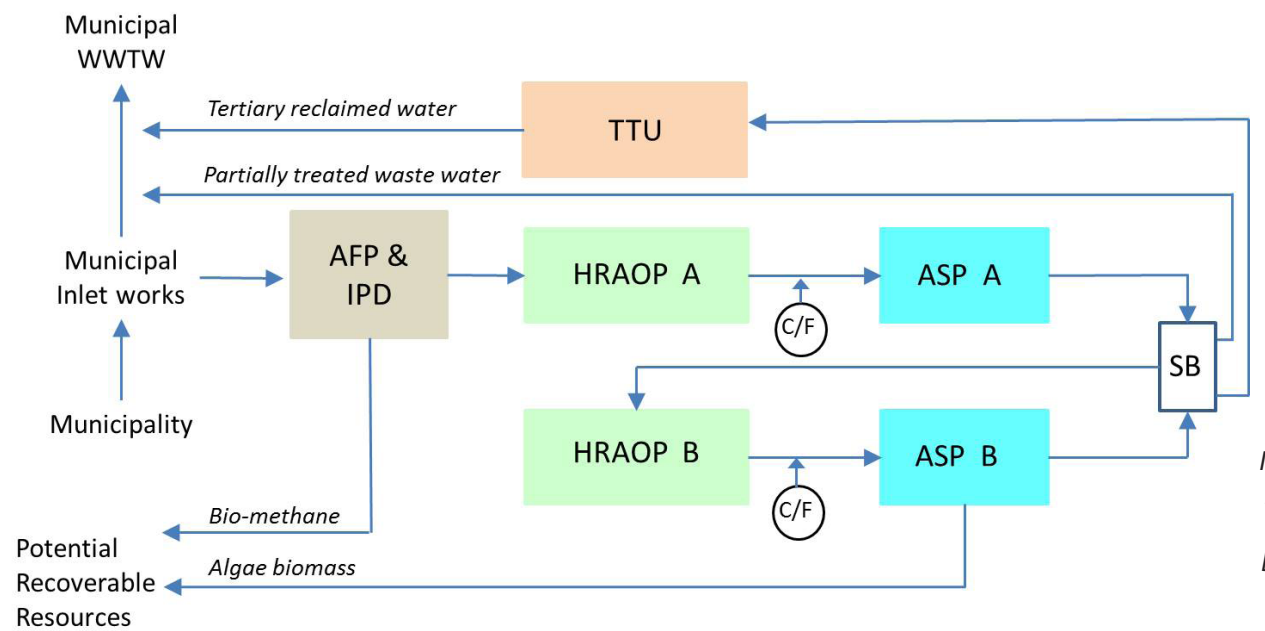

Figure 1

Schematic illustrating the process flow for the pilot IAPS designed, constructed and operational at the Belmont Valley WWTW, Grahamstown. The system receives 80-100 $\mathrm{m}^{3}$ of raw sewage daily, after screening and passage through a grit/detritus channel (in duplicate - one operating, one cleaning). Effluent enters at the bottom of the AFP some $6 \mathrm{~m}$ below water level. $A F P=$ Advanced Facultative Pond; $I P D=$ In-Pond Digester; $H R P=$ High Rate Pond; $\mathrm{C} / \mathrm{F}=$ Coagulation/Flocculation; $A S P=$ Algae Settling Pond; $S B=$ Splitter Box; TTU=Tertiary Treatment Unit (e.g. maturation pond, slow sand filter) process flow illustrating the configuration for operation of the Belmont Valley WWTW IAPS is presented in Fig. 1. The system has been in continuous operation since 1996 and receives $75 \mathrm{~m}^{3} \cdot \mathrm{d}^{-1}$ of raw sewage. It is apparent from the schematic (Fig. 1) that any partially treated water and/or tertiary treated water (i.e. suitable for reclamation) is returned to the Belmont Valley WWTW. Thus, and due to research and development needs and various logistical issues, no effluent from this demonstration system is discharged to environment. While this IAPS is an operational, passive, sequential, sewage treatment facility that functions virtually in perpetuity and without any need for faecal sludge handling, the technology has yet to be adopted by the wastewater sector for implementation nationally. The reasons for the status quo are unclear, but in part may be due to ignorance about the technology, the perception that the final effluent generated does not comply with standards set by DWA, a perceived skills shortage, and an apparent lack of will to address sewage treatment management issues, due mainly to the high costs of infrastructure repair and upgrade. This is in direct contrast with global sentiment to IAPS/AIWPS technology which is currently in use in the USA, India, New Zealand and many other countries (Table 1; Benemann, 2010).

Criteria for the Belmont Valley IAPS for the treatment of municipal sewage were as follows: capacity of 500 person equivalents $(\mathrm{PE})$ - based on an average water consumption and disposal per capita of $150 \mathrm{l} \cdot \mathrm{d}^{-1}$, the design flow was calculated at $75 \mathrm{~m}^{3} \cdot \mathrm{d}^{-1}$. With an ultimate biochemical oxygen demand $\left(\mathrm{BOD}_{\text {ult }}\right)$ assumed to be $80 \mathrm{~g} \mathrm{BOD}_{\text {ult }}$ per person per day, an organic loading to the system of $40 \mathrm{~kg} \cdot \mathrm{d}^{-1}$ was determined (Rose et al., 2002). It was postulated that the resultant treated effluent would comply with environmental discharge (Rose et al., 2007).

To eliminate the need for faecal sludge handling and disposal and to ensure complete breakdown of biodegradable solids, the volumetric capacity of the IPD was designed at $0.45 \mathrm{~m}^{3}$ per capita, rather than the more conventional $0.3 \mathrm{~m}^{3}$ per capita. Thus, raw sewage, after screening, enters at least $6 \mathrm{~m}$ below water level near the bottom of the IPD. A 'berm' wall ( $1.5 \mathrm{~m}$ below water level) extends the IPD $1.5 \mathrm{~m}$ above the floor of the AFP to direct gas flow and prevent any ingress of oxygenrich water. An upflow velocity of $1.0-1.5 \mathrm{~m} \cdot \mathrm{d}^{-1}$ in the IPD was estimated as sufficient to allow solids to settle and parasites (e.g. helminth ova, worms, etc.) to remain in the sludge layer. With a volumetric capacity of $225 \mathrm{~m}^{3}$ hydraulic retention time (HRT) in the IPD and at the designed flow is $3 \mathrm{~d}$. By reducing influent flow rate or increasing IPD volume it is possible to manage digestion to near completion. The overlying water of the AFP contains an oxygen-rich layer near the surface which is populated by algae which sequester many gases produced as a consequence of anaerobic digestion. Even so, large emissions of $\mathrm{CO}_{2}$ and $\mathrm{CH}_{4}$ from the surface area can be expected and methane production rates of $0.17 \mathrm{~kg} \mathrm{CH}_{4} \cdot \mathrm{kg}^{-1} \mathrm{BOD}_{\text {waste }}$ have been modelled for anaerobic ponds fed municipal waste (DeGarie et al., 2000; Van der Steen et al. 2003). Furthermore, about $3.3 \mathrm{~m}^{3} \cdot \mathrm{capita}^{-1} \cdot \mathrm{y}^{-1}$ of $\mathrm{CH}_{4}$ is produced in real-scale ponds at a daily sewage production of $100 \mathrm{~g}$ COD $\cdot c a p i t a^{-1} \cdot d^{-1}$. While $\mathrm{CO}_{2}$ is the best studied and most known, $\mathrm{CH}_{4}$, which constitutes up to $75 \%$ of the total gas emitted during anaerobic wastewater treatment, is 25 times more potent as a greenhouse gas (Forster et al., 2007; Daelman et al., 2012). Similarly nitrous oxide, although emitted in relatively low amounts, is 300 times more damaging than $\mathrm{CO}_{2}$ (Daelman et al., 2012; Strutt et al., 2008). While, harvesting and/or recycling of these gases can potentially avert any detrimental impact (Oswald, 1995; Green et al., 1995a), it is now understood that methane-oxidising bacteria (MOB), a relatively common group of bacteria capable of utilising $\mathrm{CH}_{4}$ as their sole carbon and energy source if sufficient $\mathrm{O}_{2}$ is present, utilise in-pond algae-derived $\mathrm{O}_{2}$ to consume much of the emitted $\mathrm{CH}_{4}$ before it reaches the atmosphere (Van der $\mathrm{Ha}$ et al., 2011; authors' unpublished data). Even so, only part of the $\mathrm{CH}_{4}$ produced by methanogens is consumed by MOB before it reaches the atmosphere and elementary extrapolation of measured pond emissions still show a total loss of about $3000 \mathrm{~m}^{3} \cdot \mathrm{y}^{-1} \mathrm{CH}_{4}$, equalling a yearly contribution of 55 ton $\mathrm{CO}_{2}$ equivalents $\cdot \mathrm{y}^{1}$ or an emission of $0.98 \mathrm{~kg} \cdot \mathrm{y}^{1} \mathrm{CH}_{4}$ per inhabitant.

For the AFP, HRT was determined using a temperaturedependent first-order decay rate for residual BOD (Rose et al., 2002) and for the Belmont Valley IAPS this is 20 days. Design of the outer reaches of the AFP was also important to limit, if not prevent, short-circuiting from the IPD overflow to the AFP outlet, which is typically $0.5-1.0 \mathrm{~m}$ below water surface to avoid skimming off of floating material and algae.

Effluent from the AFP is gravity fed to the first of 2 HRAOPs connected in series and with a combined HRT of 6 days, is subjected to photosynthetic oxygenation. High-rate algae oxidation ponds are shallow, paddlewheel-driven, continuously mixed raceways that promote algae growth. High photosynthetic rates elevate effluent $\mathrm{pH}$ (up to 11) and increase the dissolved oxygen concentration (DO; up to 3 times saturation). Excess oxygen is consumed by heterotrophic bacteria to degrade dissolved organic matter for assimilation by the algae biomass. At elevated $\mathrm{pH}$ other mechanisms also operate 
to reduce the nutrient load, e.g. phosphate precipitation and ammonia volatilisation.

Mixing, or turbulent flow, is essential to maintain optimum conditions for maximum production of microalgae. Apart from preventing thermal and oxygen stratification, paddlewheel mixing maintains the surface velocity required, keeping the algae and algal flocs suspended near the surface and within the sunlight penetration depth. A channel velocity of $50 \mathrm{~mm} \cdot \mathrm{s}^{-1}$ is sufficient to prevent algae settling and eliminate stratification but is very difficult to maintain due to frictional losses, especially in the bends. Thus, a linear velocity of $200-300 \mathrm{~mm} \cdot \mathrm{s}^{-1}$ is routinely used although this increases the energy demand. Power to drive the paddlewheels is a function of raceway length, wetted area, method of construction and channel velocity (note; friction increases as the square of the velocity increases). For raceway mixing a paddlewheel is, possibly by far, the most efficient means of consistently maintaining channel velocity. Paddlewheels are essentially pumps and as such provide the power to overcome the static head required to override frictional head loss in the raceway. Design and construction of the volute and the pump (paddlewheel) is thus very important. An 8-paddle configuration is sufficient to reduce shock on the drive and mounting assembly. Even flow velocity around the $180^{\circ}$ bends is achieved using flow rectifiers. Various flow rectifiers have been tested, teardrops, reverse teardrops, etc., and the method determined as most successful is concentric semicircle walls spaced $1 \mathrm{~m}$ apart. Biomass produced in the HRAOPs must be removed prior to tertiary treatment or discharge of the effluent and this is achieved using algae settling ponds (ASPs). Algae in the effluent settle rapidly in a well-designed ASP and a HRT of $0.5 \mathrm{~d}$ in this pond is sufficient for adequate settling. Details of the design configuration and operation of this IAPS are described elsewhere (Rose et al., 2002, 2007).

The pilot-scale IAPS described above was commissioned at the Belmont Valley WWTW in Grahamstown in 1996, to demonstrate and evaluate the performance of the system for deployment as a green technology to address issues such as climate change (Rose et al., 2002) and sustainable development (Oswald et al., 1957). The costs associated with construction and operation (including maintenance) of the IAPS were, at the time, viewed as highly competitive (Rose et al., 2002). Job creation was evidently possible (Rose et al., 2002; Harun et al., 2010) while improved access to clean water was and still is understood to stimulate social and economic development (Oswald, 1995). An extended study to evaluate operation and performance of this IAPS as a full municipal sewage treatment system for South Africa was published in 2007 and revealed the following:

- The system did not achieve the $75 \mathrm{mg} \cdot \ell^{-1}$ discharge standard for CODt.

- Although a reduction in phosphate was observed, it was not within the $10 \mathrm{mg} \cdot \ell^{-1}$ required for discharge.

- Residual ammonia levels exceeded the $3 \mathrm{mg} \cdot \ell^{-1}$ discharge standard.

- Nitrate removal was at best erratic and at times nitrate concentration increased (Rose et al., 2007).

It is difficult to reference the data obtained from the IAPS at the Belmont Valley WWTW (Rose et al., 2007) against results for other systems due in part to incompleteness in mass balances and the apparent lack of empirical values to describe the nutrient load in both the raw sewage influent as well as the residual nutrient load in the final effluent (i.e. discharged from the final ASP) following treatment by operation of the full system. Also, these authors seemed more concerned with the performance of each of the component parts of the IAPS and little emphasis was placed on IAPS as a complete system for municipal sewage treatment. Consequently, much of the data is derived from operation of only a single HRAOP and attempts to develop this further as the 'I-HRAP' for use as a tertiary treatment unit.

A further concern with the studies described by Rose et al. (2007) on the implementation and performance of the IAPS for sewage treatment in South Africa is the absence of a final polishing step. As discussed above, the original AIWPS was designed to always include a polishing step comprising of either a MP or similar which would allow the final effluent to meet the specifications for discharge as required by DWA, except for the presence of total coliforms which requires additional disinfection (e.g. chlorination, ozonation, UV-radiation, etc.). In fact, a recent report on the operation of hectare-scale HRAOPs for enhanced sewage treatment (Craggs et al., 2012) strongly advocates that additional treatment of the algae harvester effluent is required to meet specific discharge standards. These authors recommend the inclusion of one or a combination of MP and UV treatment by storage prior to discharge or rock filtration of the MP effluent or direct UV treatment if insufficient land is available, and, if funds are available, membrane filtration to achieve a high-quality final effluent for re-use. Without a final polishing step, and as demonstrated in other studies, the COD of the final effluent remains elevated resulting in the potential that, if discharged, water from an IAPS will be detrimental to any receiving water bodies (Park and Craggs, 2011). Thus, it is surprising that the model proposed by Rose et al. (2007) to link water treatment and job creation initiatives 'which is dependent on the system to produce a water quality that at least meets DWA irrigation water discharge standards' was based on a 'secondary treated' water. Clearly, any considered implementation of IAPS technology for treatment of municipal sewage must include in the process design a final effluent polishing process.

Studies underway and funded by the Water Research Commission are currently addressing the above issues in detail. Furthermore, data on compliance of final water quality, following an 8-month extended study of the system for treatment of municipal sewage, has been completed. Results show that treated water from the IAPS is compliant with the discharge limits for phosphate, ammonium-N and nitrate/nitrite- $\mathrm{N}$, and mean values were: $5.3 \mathrm{mg} \cdot \ell^{-1}, 2.9 \mathrm{mg} \cdot \ell^{-1}$, and $12.4 \mathrm{mg} \cdot \ell^{-1}$, respectively. Chemical oxygen demand however fluctuated significantly and was dependent on full function of the IAPS. Mean COD of the final treated water was $72.2 \mathrm{mg} \cdot \ell^{-1}$. Although, these results suggest that the treated water discharged from this IAPS operating under South African conditions meets the standard for discharge, mean TSS was routinely above the limit at $34.5 \pm 13 \mathrm{mg} \cdot \ell^{-1}$ and faecal coliforms were higher than expected. Tertiary treatment, either by a maturation pond series, slow sand filtration, or a controlled rock filter, ensured that the final treated water from IAPS met the standards with $\mathrm{CRF}>\mathrm{SSF}>\mathrm{MP}$ (Mambo et al., in press).

\section{Future of IAPS in South Africa}

Despite the oversights and shortcomings alluded to already, IAPS is a technology that can be used to address some of the current challenges associated with sewage treatment and management in South Africa (Rose et al., 2002). Although there may be reservations around the quality of the final effluent from IAPS, current opinion is that these bioprocess systems are more cost-competitive to design, construct and operate than 
conventional sewage treatment technologies (Rose et al., 2002). Also, IAPS is a robust technology and is not energy demanding, thereby making sewage treatment sustainable and efficient (Oswald, 1995).

No chemical dosing is required for disinfection or sludge dewatering to improve the quality of the effluent generated by the IAPS (Oswald, 1988). Thus remediation of a secondary toxic sludge is not required (Lettinga, 1996) and the effluent generated can immediately be used for irrigation and aquaculture (Oswald, 1991). While IAPS can apparently be configured to generate a desired effluent quality depending on the degree of water treatment required (Rose et al., 2002), major disadvantages include the large land areas required in comparison to electrochemical treatment systems and reverse osmosis plants (Craggs et al., 2012), and the over-reliance on bioflocculation to remove algae from the final effluent. In addition, the higher than desirable COD can potentially be detrimental to receiving water bodies (Park and Craggs, 2011). These concerns aside, introduction of a more efficient system for separating out the algae (e.g. drum filtration, dissolved air flotation) and the implementation of a tertiary treatment step should allay any further scepticism and is easily achieved either by extending the facility at the Belmont Valley WWTW or by building a fully commercial system to allow for a thorough evaluation of IAPS as a sewage treatment technology under South African conditions.

\section{CONCLUSION}

The World Health Organisation estimated that in 2000 approximately 2.4 billion people did not have access to clean water and sanitation, which led to 1.7 million preventable deaths. Successful wastewater management reduces faecal-oral disease and environmental pollution caused by sewage (Cisneros, 2011). Furthermore, nearly $50 \%$ of the 7 billion people on Earth live in water-stressed countries and it is crucial therefore that sustainable water and wastewater management technologies are implemented and practised. In view of the ever-increasing cost of energy one candidate that deserves further scrutiny and consideration, at least for waste-water management, is IAPS. Optimal conditions for an IAPS include light, sufficient land and warm temperatures. These conditions are in abundance in southern Africa. What remains is derivation of a comprehensive dataset which analyses and evaluates this bioprocess technology to provide authorities with the confidence needed when deciding on the implementation of an appropriate treatment technology. Satisfactory remediation of municipal sewage can reduce demand on potable water resources and reduce any detrimental anthropogenic imprint on the environment.

\section{ACKNOWLEDGEMENT}

Financial support is from the Water Research Commission (WRC) of South Africa through a WRC Project (No. K5/2123) awarded to Prof AK Cowan of Rhodes University. Mr Dirk Westensee acknowledges receipt of a partial bursary from NRF grant (IFR1202220169) awarded to Prof AK Cowan.

\section{REFERENCES}

ADEWUMI JR, ILEMOBADE AA and VAN ZYL JE (2010) Treated wastewater reuse in South Africa: Overview, potential and challenges. Res. Conserv. Recy. 55 (2) 221-231.

AHMAD AL, YASIN NHM, DEREK CJC and LIM JK (2011)
Microalgae as a sustainable energy source for biodiesel production: A review. Renew. Sust. Energ. Rev. 15 (1) 584-593.

ANSA EDO, LUBBERDING HJ, AMPOFO JA, AMEGBE GB and GIJZEN HJ (2012) Attachment of faecal coliform and macroinvertebrate activity in the removal of faecal coliform in domestic wastewater treatment pond systems. Ecol. Eng. 42 35-41.

BDOUR AN, HAMDI MR and TARAWNEH Z (2009) Perspectives on sustainable wastewater treatment technologies and reuse options in the urban areas of the Mediterranean region. Desalination 237 (1-3) 162-174.

BENEMANN JR (2010) Personal communication, October 2010. CEO, MicroBio Engineering, Inc., P.O. Box 15821, San Luis Obispo, CA, U.S.A.

BENEMANN JR, VAN OLST JC, MASSINGILL MJ, CARLBERG JA, WEISSMAN JC and BRUNE DE (2003) The controlled eutrophication process: Using microalgae for $\mathrm{CO}_{2}$ utilization and agricultural fertilizer recycling, In: Gale J and Kaya Y (eds.) Greenhouse Gas Control Technologies - 6th International Conference, Pergamon, Oxford. 1433-1438.

BOSHOFF G, DUNCAN J and ROSE PD (2004) The use of microalgal biomass as a carbon source for biological sulphate reducing systems. Water Res. 38 (11) 2659-2666.

BROEKHUIZEN N, PARK JBK, MCBRIDE GB and CRAGGS RJ (2012) Modification, calibration and verification of the IWA River Water Quality Model to simulate a pilot-scale high rate algal pond. Water Res. 46 (9) 2911-2926.

CHAN YJ, CHONG MF, LAW CL and HASSELL DG (2009) A review on anaerobic-aerobic treatment of industrial and municipal wastewater. Chem. Eng. J. 155 (1-2) 1-18.

CHEN P, ZHOU Q, PAING J, LE H and PICOT B (2003) Nutrient removal by the integrated use of high rate algal ponds and macrophyte systems in China48 (2) 251-257.

CISNEROS BJ (2011) Safe sanitation in low economic development areas. In: Wilderer P (ed.) Treatise on Water Science. Elsevier, Oxford. 147-200.

CRAGGS RJ (2005) Advanced integrated wastewater ponds. In: Shilton A (ed.) Pond Treatment Technology. IWA Scientific and Technical Report Series. IWA, London. 282-310.

CRAGGS RJ, ADEY WH, JENSON KR, ST. JOHN MS, GREEN FB and OSWALD WJ (1996a) Phosphorus removal from wastewater using an algal turf scrubber. Water Sci. Technol. 33 (7) 191-198.

CRAGGS RJ, ADEY WH, JESSUP BK and OSWALD WJ (1996b) A controlled stream mesocosm for tertiary treatment of sewage. Ecol. Eng. 6 (1-3) 149-169.

CRAGGS RJ, DAVIES-COLLEY RJ, TANNER CC and SUKLAS JP (2003) Advanced pond system: Performance with high rate ponds of different depths and areas. Water Sci. Technol. 48 (2) 259-267.

CRAGGS RJ, HEUBECK S, LUNDQUIST TJ and BENEMANN JR (2011) Algae biofuel from wastewater treatment high rate algal ponds. Water Sci. Technol. 63 (4) 660-665.

CRAGGS R, SUTHERLAND D and CAMPBELL H (2012) Hectarescale demonstration of high rate algal ponds for enhanced wastewater treatment and biofuel production. J. Appl. Phycol. 24 (3) 329-337.

DAELMAN MRJ, VAN VOORTHUIZEN EM, VAN DONGEN UGJM, VOLCKE EIP and VAN LOOSDRECHT MCM (2012) Methane emission during municipal wastewater treatment. Water Res. 46 (11) $3657-3670$.

DEBELIUS B, FORJA JM, DELVALLS Á and LUBIÁN LM (2009) Toxicity and bioaccumulation of copper and lead in five marine microalgae. Ecotox. Environ. Saf. 72 (5) 1503-1513.

DEGARIE CJ, CRAPPER T, HOWE BM and MCCARTHY PJ (2000) Floating geomembrane covers for odour control and biogas collection and utilization in municipal lagoons. Water Sci. Technol. 42 291-298.

DOWNING JB, BRACCO E, GREEN FB, KU AY, LUNDQUIST TJ and ZUBIETA IX (2002) Low cost reclamation using the advanced integrated wastewater pond systems technology and reverse osmosis. Water Sci. Technol. 45 (1) 117-125.

EL HAMOURI B, RAMI A and VASEL JL (2003) The reasons behind the performance superiority of a high rate algal pond over three facultative ponds in series. Water Sci. Technol. 48 (2) 269-276. 
FORSTER P, RAMASWAMY V, ARTAXO P, BERNTSEN T, BETTS R, FAHEY DW, HAYWOOD J, LEAN J, LOWE DC, MYHRE G, NGANGA J, PRINN R, RAGA G, SCHULZ M and VAN DORLAND R (2007) Changes in atmospheric constituents and in radiative forcing. In: Solomon SD, Qin M, Manning Z, Chen M, Marquis KB, Averyt M, Tignor and Miller HL (eds.) Climate Change 2007: The Physical Science Basis. Contribution of Working Group I to the Fourth Assessment Report of the Intergovernmental Panel on Climate Change. Cambridge University Press, Cambridge.

GARCÍA J, GREEN BF, LUNDQUIST T, MUJERIEGO R, HERNÁNDEZ-MARINÉ M and OSWALD WJ (2006) Long term diurnal variations in contaminant removal in high rate ponds treating urban wastewater. Bioresour. Technol. 97 (14) 1709-1715.

GARCÍA J, MUJERIEGO R and HERNANDEZ-MARINE M (2000) High rate algal pond operating strategies for urban wastewater nitrogen removal. J. Appl. Phycol. 12 331-339.

GHOSHAL D and GOYAL A (2001) Oxygen inhibition of dissolved inorganic carbon uptake in unicellular green algae. Phycol. Res. 49 319-324.

GOLUEKE CG and OSWALD WJ (1963) Power from solar energy-via algae-produced methane. Sol. Energ. 7 (3) 86-92.

GONZÁLEZ R, GARCÍA-BALBOA C, ROUCO M, LOPEZ-RODAS V and COSTAS E (2012) Adaptation of microalgae to lindane: A new approach for bioremediation. Aquat. Toxicol. 109 25-32.

GORI R, JIANG L, SOBHANI R and ROSSO D (2011) Effects of soluble and particulate substrate on the carbon and energy footprint of wastewater treatment processes. Water Res. 45 (18) 5858-5872.

GRAVELET-BLONDIN LR, BARCLAY SJ, CARLIELL CM and BUCKLEY CA (1997) Management of water resources in South Africa with respect to the textile industry. Water Sci. Technol. 36 (2-3) 303-310.

GREEN FB, BERNSTONE L, LUNDQUIST TJ, MUIR J, TRESAN RB and OSWALD WJ (1995a) Methane fermentation, submerged gas collection, and the fate of carbon in advanced integrated wastewater pond systems. Water Sci. Technol. 31 (12) 55-65.

GREEN FB, BERNSTONE LS, LUNDQUIST TJ and OSWALD WJ (1996) Advanced integrated wastewater pond systems for nitrogen removal. Water Sci. Technol. 33 (7) 207-217.

GREEN FB, LUNDQUIST TJ and OSWALD WJ (1995b) Energetics of advanced integrated wastewater pond systems. Water Sci. Technol. 31 (12) 9-20.

GROBBELAAR JU (2007) Photosynthetic characteristics of Spirulina platensis grown in commercial-scale open outdoor raceway ponds: what do the organisms tell us? J. Appl. Phycol. 19 591-598.

GRÖNLUND E, KLANG A, FALK S and HANÆUS J (2004) Sustainability of wastewater treatment with microalgae in cold climate, evaluated with energy and socio-ecological principles. 22 (3) 155-174.

HARUN R, SINGH M, FORDE GM and DANQUAH MK (2010) Bioprocess engineering of microalgae to produce a variety of consumer products. Renew. Sust. Energ. Rev. 14 (3) 1037-1047.

HORJUS F, KERSTHOLT M, STÖCKER T and COWAN AK (2010) Afvalwaterzuivering in Zuid-Afrika op basis van algen. $\mathrm{H} 2 \mathrm{O} 13$ 22-23.

JOHNSON M, CAMARGO VALERO MA and MARA DD (2007) Maturation ponds, rock filters and reedbeds in the UK: statistical analysis of winter performance. Water Sci. Technol. 55 (11) 135-142.

KATUKIZA AY, RONTELTAP M, NIWAGABA CB, FOPPEN JWA, KANSIIME F and LENS PNL (2012) Sustainable sanitation technology options for urban slums. Biotechnol. Adv. 30 (5) 964-978.

KAYOMBO S, MBWETTE TSA, KATIMA JHY, LADEGAARD N and JФRGENSEN SE (2005) Stabilization ponds and constructed wetlands design manual. UNEP-IETC and Danida. URL: http:// www.unep.or.jp/ietc/publications/water_sanitation/ponds_and_ wetlands/ design_manual.pdf (Accessed May 2012).

KORF AW, WILKEN JW and NEL NJ (1996) Strategies and management models for metropolitan wastewater, implementation and evaluation in the East Rand, South Africa. Water Sci. Technol. 34 (12) 101-108
LAXTON I (2010) Golden pond? Water Sewage Effluent 30 (1)35-43.

LETTINGA G (1996) Sustainable integrated biological wastewater treatment. Water Sci. T echnol. 33 (3) 85-98.

LIDE DR (2006) Handbook of Chemistry and Physics (87 $7^{\text {th }}$ edn.). CRC Press, Boca Raton.

LILLO C, SMITH LH, NIMMO HG AND WILKINS MB (1996) Light/ dark regulation of nitrate reductase and phosphoenol carboxylase in barley protoplasts. Planta 200 (2) 181-185.

LUDWIG HF and OSWALD WJ (1952) Role of algae in sewage oxidation ponds. Sci. Monthly 74 (1) 3-6.

LUDWIG HF, OSWALD WJ, GOTAAS HB and LYNCH V (1951) Algae symbiosis in oxidation ponds: I. Growth characteristics of Euglena gracilis cultured in sewage. Sewage Ind. Wastes 23 (11) 1337-1355.

MAMBO PM, WESTENSEE DK, RENDER DS and COWAN AK (in press) Operation of an integrated algae pond system for the treatment of municipal sewage: A South African case study. Water Sci. Technol.

MARA DD (2005) Pond process design-a practical guide. In: Shilton A (ed.) Pond Treatment Technology. Integrated Environmental Technology Series. IWA publishing, London.

MISTRIK I and ULLRICH CI (1996) Mechanism of anion uptake in plant roots: Quantitative evaluation of $\mathrm{H}^{+} / \mathrm{NO}_{3}{ }^{-}$and $\mathrm{H}^{+} / \mathrm{H}_{2} \mathrm{PO}_{4}$ stoichiometries. Plant Physiol. Biochem. 34 629-636.

MITCHELL R (1974) Introduction to Environmental Microbiology. Prentice-Hall, NJ, USA.

MO W and ZHANG Q (2012) Can municipal wastewater treatment systems be carbon neutral? J. Environ. Manage. 112 360-367.

MUGA HE and MIHELCIC JR (2008) Sustainability of wastewater treatment technologies. J. Environ. Manage. 88 (3) 437-447.

OLLER I, MALATO S and SÁNCHEZ-PÉREZ JA (2011) Combination of advanced oxidation processes and biological treatments for wastewater decontamination-A review. Sci. Total Environ. 409 (20) 4141-4166.

OSWALD O, MARTIN T, DOMINY PJ and GRAHAM IA (2001) Plastid redox state and sugars: Interactive regulators of nuclearencoded photosynthetic gene expression. Proc. Natl. Acad. Sci. 98 (4) 2047-2052.

OSWALD WJ (1988) The role of microalgae in liquid waste treatment and reclamation. In: Lembi CA and Waaland JR (eds.) Algae and Human Affairs. Cambridge University Press, Cambridge. 255-281.

OSWALD WJ (1991) Terrestrial approaches to integration of waste treatment. Waste Manage. Res. 9 (5) 477-484.

OSWALD WJ (1995) Ponds in the $21^{\text {st }}$ Century. Water Sci. Technol. 31 (12) $1-8$.

OSWALD WJ, ASCE AM and GOTAAS HB (1955) Photosynthesis in sewage treatment. Am. Soc. Civ. Eng. 2849 (686) 73-105.

OSWALD WJ, GOTAAS HB, GOLUEKE CG, KELLEN WR, GLOYNA EF and HERMANN ER (1957) Algae in waste treatment [with Discussion]. Sewage Ind. Wastes 29 (4) 437-457.

OSWALD WJ, GOTAAS HB, LUDWIG HF and LYNCH V (1953b) Algae Symbiosis in oxidation ponds: III. Photosynthetic oxygenation. Sewage Ind. Wastes 25 (6) 692-705.

PARK JBK and CRAGGS RJ (2011) Nutrient removal in wastewater treatment high rate algal ponds with carbon dioxide addition. Water Sci. Technol. 63 (8) 1758-1764.

PARK JBK, CRAGGS RJ and SHILTON AN (2011a) Recycling algae to improve species control and harvest efficiency from a high rate algal pond. Water Res. 45 (20) 6637-6649.

PARK JBK, CRAGGS RJ and SHILTON AN (2011b) Wastewater treatment high rate algal ponds for biofuel production. Bioresour. Technol. 102 35-42.

PATUREAU D, BERNET N and MOLETTA R (1996) Effect of oxygen on denitrification in continuous chemostat culture with Comamonas sp SGLY2. J. Ind. Microbiol. 16 124-128.

RAVEN JA and HURD CL (2012) Ecophysiology of photosynthesis in macroalgae. Photosynth. Res. 113 105-125.

REPUBLIC OF SOUTH AFRICA (2008) National Environmental Management: Waste Act (Act 59 of 2008). Government Gazette, Vol. 525, No. 32000, Cape Town.

RITCHIE RJ and LARKUM A (2013) Modelling photosynthesis in shallow algal production ponds. Photosynthesis 50 (4) 481-500. 
RODRIGUEZ-GARCIA G, HOSPIDO A, BAGLEY DM, MOREIRA MT and FEIJOO G (2012) A methodology to estimate greenhouse gases emissions in life cycle inventories of wastewater treatment plants. Environ. Impact Assess. Rev. 37 37-46.

ROSE PD, MAART BA, DUNN KM, ROWSWELL RA and BRITZ P (1996) High rate algal oxidation ponding for the treatment of tannery effluents. Water Sci. Technol. 33 (7) 219-227.

ROSE PD, HART OO, SHIPIN O and ELLIS PJ (2002) Integrated algal ponding systems and the treatment of domestic and industrial wastewaters. Part 1: The AIWPS model. WRC Report No. TT 190/02. Water Research Commission, Pretoria.

ROSE PD, WELLS C, DEKKER L, CLARKE S, NEBA A, SHIPIN O and HART OO (2007) Integrated algal ponding systems and the treatment of domestic and industrial wastewaters. Part 4: System performance and tertiary treatment operations. WRC Report No. TT 193/07. Water Research Commission, Pretoria.

SEKOMO CB, ROUSSEAU DPL, SALEH SA and LENS PNL (2012) Heavy metal removal in duckweed and algae ponds as a polishing step for textile wastewater treatment. Ecol. Eng. 44 102-110.

SHERAMETI I, SOPORY SK, TREBICKA A, PFANNSCHMIDT T and OELMÜLLER R (2002) Photosynthetic electron transport determines nitrate reductase gene expression and activity in higher plants. J Biol. Chem. 277 (48) 46594-46600.

SHILLINGLAW SN (1977) Observations on algal populations in an experimental maturation pond system. Water SA 3 (4) 183-192.

SONUNE A and GHATE R (2004) Developments in wastewater treatment methods. Desalination 167 (0) 55-63.

STRUTT J, WILSON S, SHORNEY-DARBY H, SHAW A and BYERS A (2008) Assessing the carbon footprint of water production. J. Am. Water Works Assoc. 100 (6) 80-91.

SU Y, MENNERICH A and URBAN B (2012) Synergistic cooperation between wastewater-born algae and activated sludge for wastewater treatment: Influence of algae and sludge inoculation ratios. Bioresour. Technol. 105 67-73.

TOMAR P and SUTHAR S (2011) Urban wastewater treatment using vermi-biofiltration system. Desalination 282 95-103.

TRAVIS MJ, WEISBROD N and GROSS A (2012) Decentralized wetland-based treatment of oil-rich farm wastewater for reuse in an arid environment. Ecol. Eng. 39 81-89.
ULLRICH CI and NOVACKY AJ (1990) Extracellular and intracellular $\mathrm{pH}$ and membrane-potential changes induced by $\mathrm{K}^{+}, \mathrm{Cl}^{-}$, $\mathrm{H}_{2} \mathrm{PO}_{4}^{-}$, and $\mathrm{NO}_{3}^{-}$uptake and fusicoccin in root hairs of Limnobium stoloniferum. Plant Physiol. 94 1561-1567.

ULLRICH WR, LAZAROVÁ J, ULLRICH CI, WITT FG and APARICIO PJ (1998) Nitrate uptake and extracellular alkalinization by the green alga Hydrodictyon reticulatum in blue and red light. J. Exp. Bot. 49 (324) 1157-1162.

VAN DER HA D, BUNDERVOET B, VERSTRAETE W and BOON N (2011) A sustainable, carbon neutral methane oxidation by a partnership of methane oxidizing communities and microalgae. Water Res. 45 2845-2854.

VAN DER STEEN NP, NAKIBONEKA P, MANGALIKA L, FERRER AVM and GIJZEN H (2003) Effect of duckweed cover on greenhouse gas emissions and odour release from waste stabilisation ponds. Water Sci. Technol. 48 341-348.

VAN HILLE RP, BOSHOFF GA, ROSE PD and DUNCAN JR (1999) A continuous process for the biological treatment of heavy metal contaminated acid mine water. Resour. Conserv. Recy. 27 (1-2) 157-167.

VON SPERLING M (2007) Waste Stabilisation Ponds. Biological Wastewater Treatment Series (Vol. 2). IWA Publishing, London.

VON SPERLING M and DE LEMOS CHERNICHARO CA (2005) Biological Wastewater Treatment in Warm Climate Regions. Biological Wastewater Treatment Series (Vol. 1). IWA Publishing, London.

WANG H, OMOSA IB, KELLER AA and FENGTING L (2012) Ecosystem protection, integrated management and infrastructure are vital for improving water quality in Africa. Environ. Sci. Technol. 46 (9) 4699-4700.

WALLIS MJ, AMBROSE MR and CHAN CC (2008) Climate change: Charting a water course in an uncertain future. J. Am. Water Works Assoc. 100 (6) 70-79.

WEISSMAN JC and GOEBEL RP (1987) Factors affecting the photosynthetic yield of microalgae. In: Johnson DA (ed.) FY 1986 Aquatic Species Program Annual Report. Solar Energy Research Institute, Golden, Colorado. SERI/SP-231-3071. 139-168.

ZIMMO OR, VAN DER STEEN NP and GIJZEN HJ (2004) Quantification of nitrification and denitrification rates in algae and duckweed based wastewater treatment systems. Environ. Technol. 25 (3) 273-282. 
http://dx.doi.org/10.4314/wsa.v40i2.21 Available on website http://www.wrc.org.za

ISSN 0378-4738 (Print) $=$ Water SA Vol. 40 No. 2 April 2014 ISSN 1816-7950 (On-line) = Water SA Vol. 40 No. 2 April 2014 